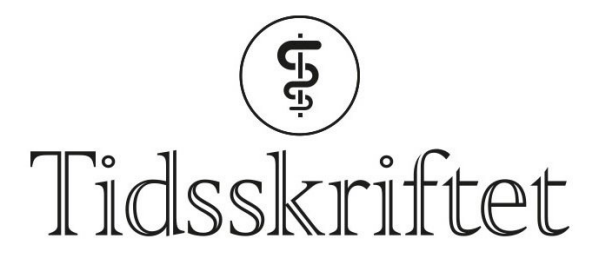

DEN NORSKE LEGEFORENING

\title{
Eventyrer i hvitt
}

INTERVJU

MARIT TVEITO

E-post: marit.tveito@aldringoghelse.no

Nasjonal kompetansetjeneste for aldring og helse

Morten Rostrup har vært på de høyeste fjell og gitt legehjelp i alle verdens kroker for Leger Uten Grenser. Denne våren trengte han ikke å reise utenlands for å gi krisehjelp.

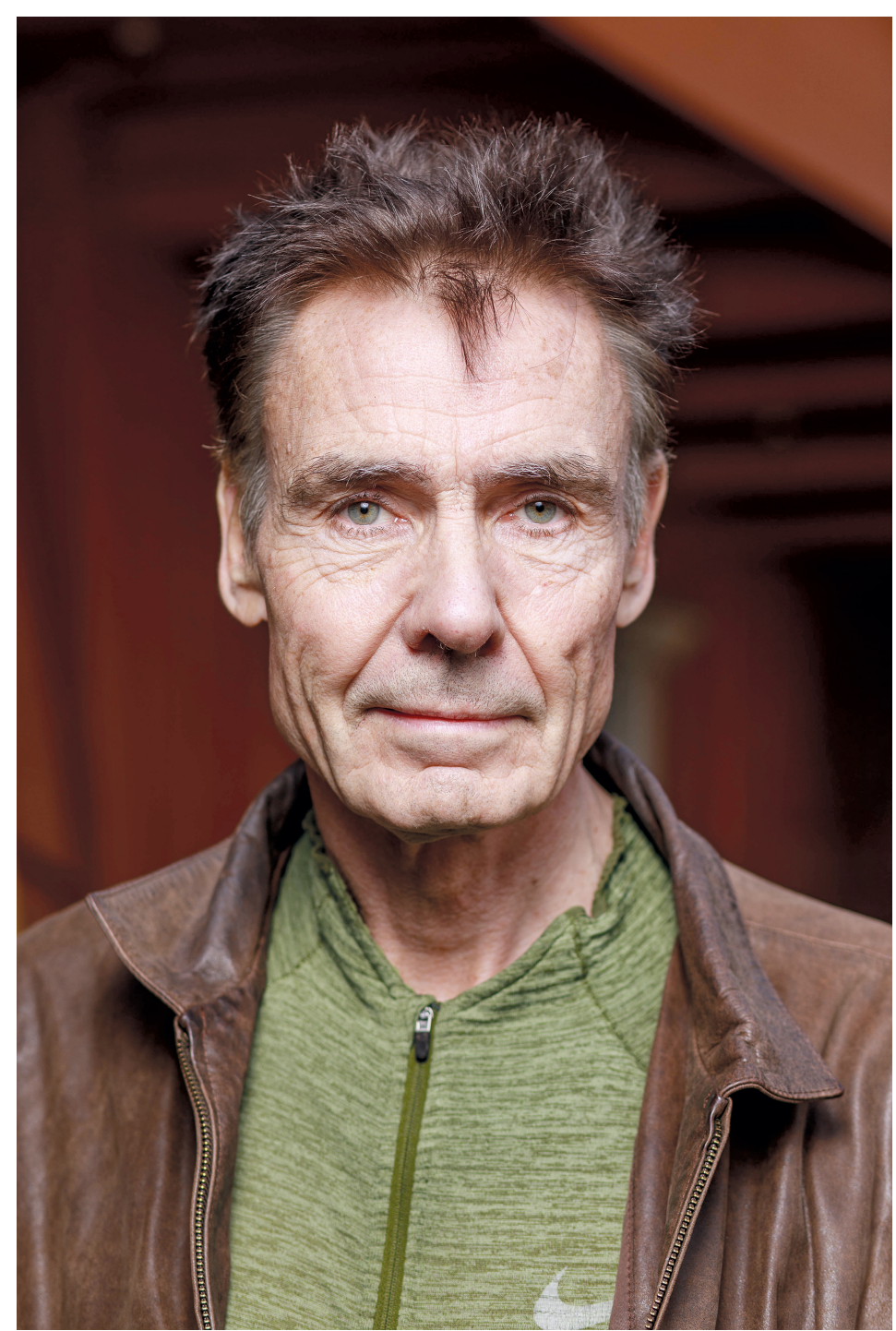

Foto: Niklas Lello

Rostrup har ledet Leger Uten Grenser internasjonalt, vært på toppen av Mount Everest, på 
listen over tidenes 100 tøffeste nordmenn i Finansavisen og ble et år kåret til årets mann av mannfolkbladet Mann. Etter å ha vært i front i alle slags helsekatastrofer i mange land stod han også i frontlinjen da den største helsekrisen i historien traff Norge i mars.

\section{Trygg havn}

- For å spole litt tilbake i tid, hvorfor ble du lege?

- Faren min var lege. Han fikk tilsendt mye reklamemateriell som var morsomt for barn å se på og leke med, blant annet spennende anatomiske plakater. Jeg ble tidlig interessert i menneskekroppen.

Familien bodde på Blindern, ikke langt fra universitetet.

- Det var en veldig stabil barndom, alt var forutsigbart. Vi hadde en liten hytte på fjellet og en liten hytte ved sjøen. Alle feriene ble tilbrakt der.

Eplet falt langt fra stammen. Rostrup har vært flere steder i verden enn de fleste.

- Jeg har fundert mye på hvorfor jeg har blitt den jeg har blitt. I slekta var det mange sjøfolk på farssiden, og jeg traff en firmenning som hadde reist til mange av de samme stedene som meg. Her ligger det noe, tenkte jeg. Nysgjerrigheten har bare hoppet over et ledd.

- Du tror ikke at trygghet og forutsigbarhet har vært en forutsetning for å tørre?

- Jo, det tror jeg nok. Jeg er veldig glad for den oppveksten.

- Så ble det turnus og spesialisering?

- Alle så nok for seg at jeg skulle ha en tradisjonell karriere, men det var ikke akkurat det som passet meg best.

- Du begynte å klatre?

- Det begynte jeg med allerede i studietiden. Da kombinerte jeg eventyrlyst, reising og klatring. Vi reiste til alle slags fjellområder. Det var utfordrende og spennende med tett teamarbeid under vanskelige forhold. Baksiden er at man kan bli nokså sneversynt. I 1996 var jeg på Mount Everest. Det var rart å se hvordan folks verdier kan endres i slike situasjoner.

For meg spiller det ingen rolle hvem som er min pasient. Det er akkurat det samme om det er et jordskjelvoffer på Haiti, et koleratilfelle i Tanzania, et offer for ebola i Liberia eller en intensivpasient i Norge

- Turen ble et vendepunkt?

- Der slo det meg: Hvorfor skulle man risikere liv og helse for dette? OK, du kommer deg på toppen av et fjell. Hundrevis har vært der før deg. Du bidrar ikke med noe nytt. Det bidrar ikke positivt for andre mennesker. Det var en veldig dramatisk ekspedisjon, selv om vår var vellykket. Åtte av oss ti kom på toppen, men flere døde eller ble alvorlig syke rundt oss. Klatrere gikk forbi andre klatrere i nød. Jeg satte mitt eget og mine klatrekameraters liv i fare ved å gi bort alt oksygenet i forsøket på å redde livet til en mann. Det var en feilvurdering.

- Hvorfor gjorde du det?

- Det er vanskelig å være i en slik situasjon som lege. Det er nærmest en refleks, vi vil alltid gjøre det vi kan for det medmennesket vi har foran oss. Da vi kom ned til 8300 meter etter å ha vært på toppen, ble jeg bedt om å hjelpe en mann som var i koma med hjerneødem. Han fikk deksametason og alt oksygenet vårt før han døde. Jeg traff kona på vei ned fra fjellet. Selv om det egentlig hadde vært for risikabelt, var det godt å kunne si at vi hadde gjort alt vi kunne. 


\section{Stammetenkning}

Rostrup ble den første norske presidenten i Leger Uten Grenser i 1996.

- Hva er det som driver deg til å reise ut for å hjelpe?

- Jeg har et yrke som gjør at jeg kan bidra på mange måter overfor andre mennesker. Jeg er mer og mer opptatt av at medisinsk humanitært arbeid er en «antitribalistisk» atferd. Vi lever i en verden hvor vi blir mer og mer selvsentrerte. Evolusjonen har skapt hjernen slik at vi har en tendens til «stammetenkning». Du kan se hvordan autokratier i verden spiller på de primitive delene av vår psykologi. Hjernen har begrenset kapasitet til å forholde seg til mer enn kanskje 250 mennesker som komplekse individer. Utover det tyr vi til stereotyper. Da jeg var i Libya under krigen der, fikk jeg spørsmål om hvorfor jeg brydde meg om de som bodde der. For meg spiller det ingen rolle hvem som er min pasient. Det er akkurat det samme om det er et jordskjelvoffer på Haiti, et koleratilfelle i Tanzania, et offer for ebola i Liberia eller en intensivpasient i Norge. Det er et medmenneske.

Du kan se for deg å jobbe mens du lurer på om en bombe kommer til å drepe både deg og pasientene

- Kan leger hjelpe flere enn den enkelte?

- Leger kan fortelle hvor sterk og universell den direkte kontakten mellom mennesker er, slik vi hele tiden opplever med pasienter. Dessverre lever vi i et samfunn hvor jeg tror vi er i ferd med å distansere oss, også på grunn av teknologien. Samfunnet blir mer inhumant, og vi blir ikke lykkelige av det. Lykken er andre mennesker. Det sosiale livet er det viktigste. Da må du også investere i det sosiale, du må satse på det. Jeg er opptatt av vennskap som noe fundamentalt for oss mennesker.

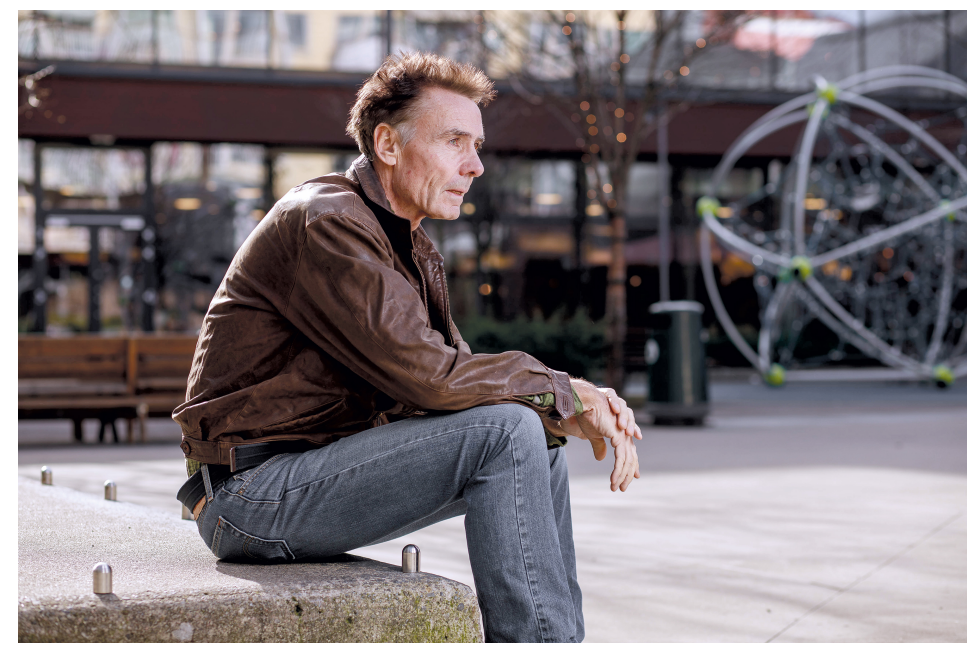

- Hvordan tar du vare på ditt sosiale liv med all reisingen?

- Jeg tror jeg er flink til det. Jeg arrangerer middager, fester og gir det stor prioritet. Det er viktig for meg som ikke har en klassisk familie.

- Hva tror du koronaviruset vil ha å si for vårt sosiale liv i tiden fremover?

- Det er vanskelig å si. Det å ha nær kontakt med andre mennesker stikker dypt i vår natur. Berøring er viktig. Samtidig er mange nå skremt av smitterisiko, og vi får nok en endret atferd med mer fokus på hygiene, i alle fall inntil denne pandemien går over i historien.

\section{En fast base}

- Du bodde lenge i sykehusleiligheter?

- Ja, ferden gikk fra kone og villa på Nordstrand til en sykehusleilighet på Ullevål. For ti år siden kjøpte jeg meg endelig en leilighet på Grønland.

- Så nå har du et hjem? 
- Det er godt å ha en base. Jeg synes det er et spennende og levende område å bo i, på godt og vondt. Jeg trives med det multikulturelle og at folk er litt forskjellige. Det er alltid liv der. Og t-banen tar meg overalt. Jeg har ikke bil.

- For å bidra til et bedre klima?

- Fordi jeg ikke har behov for bil. Jeg sykler hele året til jobb, opp langs Akerselva. Det er en fin start på dagen. Det er godt å bevege seg og være nær naturen. Natur er viktig for meg. Jeg føler harmoni i naturen, enten jeg sykler i marka eller går på ski. Det er en form for meditasjon. Jeg hører ikke på musikk. Og hvorfor i all verden skal folk høre på podkaster hele tiden? Jeg er flink til å ta livet med ro, selv om mange kanskje ikke tror det. Når jeg går i marka, flyter tankene. Hjernen trenger tid uten spesifikke oppgaver.

\section{Hjernen og hjelpearbeid}

- Du er opptatt av hjernen?

- Jeg er opptatt av hvordan vi er som mennesker. Jeg ønsker å forstå. Jeg har begynt å lese litt evolusjonspsykologi og sosialpsykologi. Vi kan lett bli manipulert og må vite om egenskapene vi har. I Myanmar opprettet myndighetene falske Facebook-profiler som spilte på psykologi og skapte polarisering som endte i vold og masseflukt. Det er spesielt viktig i våre dager å kjenne til psykologiske mekanismer. De som ønsker å manipulere oss har fått et veldig effektivt verktøy - sosiale medier. Det fantes ikke før. Tribalisme og økt polarisering forsterker konfliktnivået.

\section{Morten Rostrup}

Født 7. mars 1958

Cand.med., Universitetet i Oslo 1983

Spesialist i indremedisin 1996

Dr.med., Universitetet i Oslo 1994

President i Leger Uten Grenser 1996-2002

Internasjonal president i Médecins Sans Frontières 2000-04

Spesialist i akutt- og mottaksmedisin 2019

Overlege ved Akuttmedisinsk avdeling, Oslo universitetssykehus, Ullevål 1996-

Leder, Enhet for indremedisinsk forskning, Oslo universitetssykehus, Ullevål 2005-

Professor II, Avdeling for atferdsmedisin, Universitetet i Oslo 2015-

Han knipser med fingrene.

- Pang.

- Det har blitt vanskeligere å være hjelpearbeider?

- Mye vanskeligere. Jeg har fulgt konflikten i Syria nøye. Nå er det nærmest legitimt å bombe sykehus, skoler og markeder.

- Hjelpearbeiderne har ikke vært fiender før?

- Jeg opplevde det første gang i Libya i 2011. Blodbanken ble ødelagt. Bårebærere ble truffet av snikskyttere når de bar sårede til sykehuset. Så ble sykehuset angrepet. Det å nekte folk legehjelp ble brukt som et våpen i krigen. Hvis du som lege hjelper en som tilhører fienden, blir du selv en fiende.

Den første gangen Rostrup dro til Syria, tok han seg ulovlig over grensen.

Vi lever i en verden som aldri før har trengt så tett internasjonalt samarbeid - med tanke på pandemier, klima og andre globale utfordringer. Samtidig lever vi paradoksalt nok i en politisk tid hvor det er det motsatte som skjer, isolasjon og nasjonalisme 
- Det var en spesiell opplevelse. Jeg møtte leger som var helt fortvilet og redde. Du kan se for deg å jobbe mens du lurer på om en bombe kommer til å drepe både deg og pasientene. Syria har en ny terrorlov som gjør det ulovlig å hjelpe pasienter som kan tilhøre fienden. I Idlib-provinsen var det nylig et angrep mot noen skoler hvor mange sivile på flukt var samlet. Leger Uten Grenser støtter tre sykehus i regionen, og vi går hardt ut mot dette, så hardt vi kan. Det er forferdelig farlig når krigsforbrytelser blir normalisert. I området er det tre millioner mennesker, og en million mennesker er på flukt.

- Det er til å bli litt motløs av?

- Ja, man må spørre seg om verdenssamfunnet har noen mekanismer for å motvirke utviklingen, når stormakter ikke viser interesse for å gjøre noe. Vi lever i en verden som aldri før har trengt så tett internasjonalt samarbeid - med tanke på pandemier, klima og andre globale utfordringer. Samtidig lever vi paradoksalt nok i en politisk tid hvor det er det motsatte som skjer, isolasjon og nasjonalisme. Vi bryter ned internasjonale institusjoner. FN-systemet får mindre innflytelse - når vi trenger det som mest. WHO mister USAs $ø$ konomiske støtte. De siste som opplevde annen verdenskrig dør ut, og hukommelsen for det som skjedde i forkant av krigen og hva ekstrem nasjonalisme kan føre til, forsvinner. Etter krigen var mantraet «aldri mer krig». Nå er det en annen politikk.

- Hva med hjelpearbeid under en pandemi når nærmest alle land i verden stenger grensene?

- Dette har skapt store problemer. Det kan være vanskelig å få helsearbeidere inn i land, og transportmulighetene er svært vanskelige. Humanitære organisasjoner må nå avvente plass på fly for å vite hvem som kan reise hvor. Noen land krever sertifikater på at hjelpearbeiderne ikke er smittet av korona. Det er egentlig meningsløst, all den tid en negativ test hos en ikke-symptomatisk person likevel ikke er noen garanti.

\section{Sterke inntrykk}

- Er det noe som kan være vanskelig å legge bort etter oppdrag?

- Det er gjerne de gangene man har fulgt reglene, gjort det som var forventet, men hvor man angrer på at man ikke brøt de reglene. Jeg kan tenke på den unge gutten i Angola som ba så sårt om å få bli med til reernæringssenteret, men som ut ifra kriteriene var litt for gammel. Jeg fulgte retningslinjene og lot være. Sånne ting angrer jeg på.

Jeg har blitt mer opptatt av å gjøre det jeg føler er riktig. Jeg bryter regler. Under jordskjelvet i Haiti fikk jeg ansvar for noen alvorlig brannskadde pasienter, men vi hadde ikke det vi trengte av utstyr. Da det dukket opp et amerikansk militært hospitalskip med full intensivavdeling, fikk jeg flyttet pasientene dit. Det var ikke i henhold til regelverket, og jeg fikk mye kritikk for det. Jeg er fortsatt glad for at jeg gjorde det. I Rohingya-flyktningleiren reddet jeg livet til en liten jente som holdt på å bli kvalt av difteri. Ifølge protokollen skulle vi la henne dø. En del folk ser seg helt blinde på retningslinjer. Klinisk skjønn kan tillegges mer vekt jo mer erfaren man er. Man må kunne bruke hodet. 


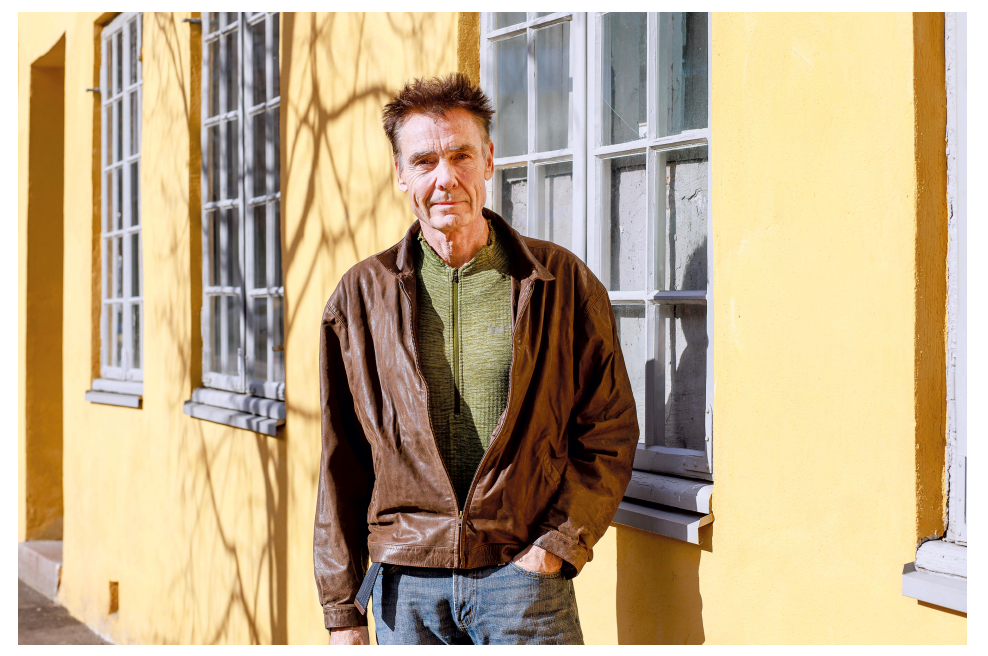

- Hva skal du gjøre fremover?

- Jeg jobber ved Akuttmedisinsk avdeling på Ullevål og stortrives der. Jeg har i alle år hatt en forståelsesfull sjef. Det har vært et bra vekselbruk. Så har jeg en bistilling ved universitetet innen atferdsmedisin. Det å undervise studenter trives jeg meget godt med. I tillegg har jeg stått litt på for å få humanitærmedisinske spørsmål inn i studiet. Jeg driver forskningsprosjekter og veileder doktorgradsstipendiater. Det tilfredsstiller nysgjerrigheten min på et annet nivå.

Rostrup kunne bruke erfaringen fra hjelpearbeid da koronaen kom til arbeidsplassen hjemme.

- Hvordan var det å stå i første rekke da pandemien traff landet?

- Jeg fikk et slags déjà vu. Noen av forberedelsene og tankene hadde jeg vært gjennom før. Først var mange redde for en katastrofe - et sammenbrudd i helsevesenet. Vi hadde hørt kolleger fra Italia som var tydelig preget av en epidemi fullstendig ute av kontroll - et helsevesen som lå nede nesten slik jeg har sett i ulike krigssoner. Antallet pasienter som vi hørte døde på intensivavdelingene, var skremmende høyt, i størrelsesorden 50-70 \%. Faktisk så jeg nylig at dødeligheten på et sykehus i New York var på nærmere go \% for respiratorpasienter. I tillegg måtte vi tenke på egen risiko for å bli smittet.

Klinisk skjønn kan tillegges mer vekt jo mer erfaren man er. Man må kunne bruke hodet

Men vi fikk kontroll i Norge. Vi har svært lav dødelighet for våre respiratorpasienter. Det avspeiler nok flere ting. Vi ser jo at USA har et stort problem med overvekt, som er en klar risikofaktor. Men svært viktig er også mulighetene helsepersonell har til å ta seg av pasientene. Noen av pasientene jeg har vært med på å behandle på intensivavdelingen har vært svært krevende og må følges nøye av leger over tid.

Jeg tenker på mine kolleger i andre land som overbelastes. En sykepleier alene har ansvar for flere pasienter og legene har ikke mulighet til å følge opp behandlingen der de løper fra den ene kritisk syke til den andre. Det har vært tilfredsstillende å jobbe i et system der vi har god kapasitet til å gi våre pasienter den best mulige behandlingen. Jeg har opplevd mange situasjoner der det ikke har vært mulig.

- Er det vanskelig å slutte med oppdrag i utlandet?

- Nei, jeg er egentlig ikke så rastløs. Jeg liker å gjøre nye ting, men også det å reise ut kan bli en rutine. Hvis jeg skal ta et oppdrag, vil jeg gjerne dra på noe hvor jeg føler at min kompetanse er viktig. På et eller annet tidspunkt blir man kanskje litt mett. Jeg synes jobben på Ullevål er fantastisk. Jeg får være med på å hjelpe andre mennesker og til og med redde liv. Hvis vi setter oss ned og tenker over verdien av det - da blir det kanskje færre utbrente.

- Du er ikke plaget av utbrenthet selv?

- Nei, men jeg tror det er viktig at mitt arbeid er svært variert. Og utbrenthet forsterkes av 
jobb-hjem-konflikten. Han knegger.

- Det eneste levende vesenet hjemme hos meg er en palme som heter Olof.

- Du er ikke så opptatt av ting?

- Nei, jeg er ikke materialistisk anlagt. Du vet (han gjentar det som virker å være et livsmotto), lykken er andre mennesker.

Publisert: 25. mai 2020. Tidsskr Nor Legeforen. DOI: 10.4045/tidsskr.20.038o

(C) Tidsskrift for Den norske legeforening 2020. Lastet ned fra tidsskriftet.no 